DOI: $10.17516 / 1997-1370-0605$

УДК $316.4 ; 316.7$

\title{
Mechanisms for Social Ties Formation in the Information Environment in Modern Domestic and Foreign Studies
}

\author{
Svetlana V. Bereziuk, Natalia P. Koptseva \\ and Antonina I. Fil'ko* \\ Siberian Federal University \\ Krasnoyarsk, Russian Federation
}

Received 05.03.2020, received in revised form 30.04.2020, accepted 08.05.2020

\begin{abstract}
This article discusses the features of the emergence and strengthening of social ties in the studies of Russian scientists and their foreign colleagues. The main emphasis is made on the research studying these processes in the modern information environment. For a complete insight of the issue, the concepts of "social ties" and "information environment", as well as their featuring in monographs and scientific articles are studied in the article. The article summarises domestic and foreign studies in this area regarding migrants and indigenous peoples. The features of the formation of social ties with relatives living remotely and fellow countrymen living in the same environment are specified. The features of expanding social ties through mobile phones and Internet communications are emphasised.
\end{abstract}

Keywords: social ties, information environment, social ties formation, social ties of migrants, social ties in the information environment.

The reported study was funded by RFBR, project number 19-39-90015. The reported study was funded by RFBR, project number 19-311-90016.

Research area: sociological sciences.

Citation: Bereziuk, S.V., Koptseva, N.P., Fil'ko, A.I. (2020). Mechanisms for social ties formation in the information environment in modern domestic and foreign studies. J. Sib. Fed. Univ. Humanit. Soc. Sci., 13(5), 762-769. DOI: 10.17516/1997-1370-0605.

\footnotetext{
(C) Siberian Federal University. All rights reserved

* Corresponding author E-mail address: svet2303@mail.ru, chalkywolf@gmail.com,decanka@mail.ru ORCID: 0000-0003-3910-7991 (Koptseva); 0000-0001-5180-1682 (Bereziuk); 0000-0002-2787-423X (Fil'ko)
} 


\section{Introduction}

The issue of social ties and interactions has always been of specific interested to sociology. Today this interest is actualised by the transformation of society into a complex dynamic system with numerous forms of interaction between people, a greater speed of these interactions and a greater remoteness.

Every year, the influence of the information environment on modern society is more and more intensified. Scientists specialising in various fields, such as cultural scientists, sociologists, computer scientists, and physicists start studying this phenomenon. Studies in this area reveal the essence of the modern information environment, as well as its impact on society as a whole.

In the framework of the research conducted in the territory of Krasnoyarsk Krai, the study of social ties formation among the indigenous peoples of the North is considered significant and relevant. The modern scientific literature presents a wide range of research related to the study of various aspects of the life and culture of indigenous peoples, each of which plays an important role in maintaining ethnic identity. It may be noted that the constructivist approach proposed by a Norwegian researcher F. Bart (2006) and developed by V.A. Tishkov (1994) and L.M. Drobizheva (2013) in domestic science, is relevant in modern ethnography. Studies related to the situation of indigenous peoples in the context of global transformations are currently relevant in the field of cultural anthropology in other countries. M. Blaser, Harvey A. Feit and G. McRae (2004) study how changes affect indigenous peoples' lifestyles, as well as offer projects for their development. B.L. Hall, G.J.S. Dei and D.G. Rosenberg (2000) study cultural knowledge of indigenous peoples regarding daily realities of life. There is a discussion of contemporary political and legal conflicts between tribal peoples and nation states and efforts to preserve the culture of indigenous peoples in the context of globalisation (Coates, Coates, 2004).

Research activity on the study of indigenous peoples living in the territory of Krasnoyarsk Krai is carried out by the scientists of
Siberian Federal University. There are studies on the issues of global transformations and their influence on the indigenous peoples of the north of Krasnoyarsk Krai (Amosova et al., 2019; Seredkina, Strucheva, 2018; Koptseva, 2014, 2017; Koptseva, Reznikova, 2015; Zamaraeva et al., 2019; Zamaraeva, Sergeeva, Fil'ko, 2018; Kolesnik et al, 2018; Sitnikova, 2018; Kistova et al., 2018).

\section{Social ties and their formation}

Supporters of network theory and network analysis make a significant contribution to the study of social ties. Researchers note the presence of two main approaches in network theory: "cultural" ("relational sociology") presented by the studies of H. White (2008), and the "actor-network" theory by B. Latour (2011) and M. Callon (1999).

In the modern concept of social ties, the concept of "social action" is a central one. Social action is an elementary unit of interaction. This concept correlates with the constructivist approach in ethnography, which describes ethnicity through the construction of interactions (Bart, 2006; Tishkov, 1994; Drobizheva, 2013). Relational sociology considers action from the point of view of the intersubjective context of relationships, which includes a single action. Structures arise from relationships and interactions. The actor-network theory (ANT), based on its name, combines actor and network into a single whole. It suggests that new forms of relationships of an individual with others arise due to the increasing role of non-human objects in a knowledge-based society and consumer culture, as well as the changing nature of objects in the structure of personality.

Social ties consist of such elements as: subjects of ties (two or more people); the object of ties based on which ties are established; the mechanism of conscious regulation of the relationship between the subjects of ties.

There are following types of social ties:

1) social contacts - common ties between individuals, usually superficial; social contacts can be single (sporadic) or regular;

2) social actions - targeted actions aimed at other people; 
3) social interactions - systematic interdependent people's actions in relation to each other;

4) social relationships - stable ties between people or groups of people, practiced over a long period of time in accordance with the norms of behaviour accepted in society, as well as the system of social roles and statuses.

M. Granovetter (2009) emphasises the importance of studying social ties and networks. He divides social ties into strong (between an individual and his/her closest environment), weak (between an individual and his/her acquaintances) and absent ones (in the situation of absence of any relationships and their insignificance).

\section{Information environment}

The information space is vast, as it comes to an individual from various sources. It is valuable and efficient only if it is adopted by a person and transformed into knowledge. The "information environment" is seen as a part of the information space, as well as a complex of conditions in which human activity is carried out.

Studying this phenomenon V.I. Vernadsky (Vernadsky, 1989; Sokolov, 2013) said the following: "Radiations of different wavelengths are around us, in us, everywhere, continuously changing, coinciding and colliding without interruption ... All space is filled with them".

And indeed, the information environment formed around a person is diverse, heterogeneous and individually perceived by every person. The information boom that was intensified in the era of post-industrial society has led to a qualitatively new perception of the information space as a whole. As a result, the reality surrounding us is radically changing - new conditions for cultural exchange and interaction appear.

Currently, every modern person can simultaneously exist in several information spaces at the same time. But the personal information field of an individual is formed at the intersection of these spaces. There are different daily impacts on the formation of an individual information environment: the development of technical means and technologies, new economic conditions, etc. Communication networks, television and computer technologies are rapidly developing.

In Russian science, the concept of the information environment was actively developed by $\mathrm{Yu}$.A. Shreider. In his opinion, the information environment is the environment "where research and development, technical and engineering activities, as well as planning and management of science and technology take place" (Shreider, 2008). The concept itself arose as a result of perception of "the common nature of the information phenomenon, manifested in the forms of existence, processing, storage and dissemination of scientific and technical information" (Shreider, 2008). The information environment is an intermediary in communication.

Contemporary information environment is a flow where information and physical means necessary for its functioning, support and development are distributed.

The information society has the following characteristics:

1) The increasing role of information in the life of a person and society as a whole, as well as its transformation into an economic factor of development;

2) The merger of various communication methods;

3) Focus on technologies contributing to high-quality information processing;

4) development of a person's creative potential, as well as the continuity of his/her culture.

For better understanding of the phenomenon of "modern information environment" it is necessary to turn to the authors who define it from different cultural positions.

Thus, according to L.A. Pronina, "the information environment is a part of the information space, the nearest to an individual external environment, the totality of the conditions in which his/her activities take place" (Pronina, 2009).

M.A. Smirnov, in turn, says that the modern information environment is "a set of informational conditions for a person's existence" (Smirnov, 2001). 
Having studied this aspect, T.F. Berestova sees it as "a form of interaction of subjects with each other and with information objects in order to create information and provide conditions for its use" (Berestova, 2016).

The modern information environment is a product of society with a predominance of mass culture and communication, and their clash occurs through the use of mass communication. It gives rise to its own analogues of reality, its own virtual world where traditional reality is partially distorted. By changing the social reality of a person, the information environment makes adjustments to his nature.

Considering the modern information environment through the prism of general regularities and patterns, it is possible to distinguish the following: firstly, due to globalisation, it is constantly increasing, capturing new spheres of human life; secondly, having a huge impact on a modern person' life, it reflects the main forms of social relations between people in its resources; thirdly, it is able to create its own reality, its own digital world.

The modern information environment acts as the habitat of information and is a multi-level formation, consisting of individual characteristics of each person, public opinion and mass media.

Some Russian scientists consider the information environment as an environment of network virtual interaction, with an automated information system as its technological basis (Krevskii et al., 2014; Maksimov, 2009). The information environment is also assessed in terms of the current state of television and the Internet as types of mass media (Nazarov, Kovalev, 2014).

K.A. Kalyuzhnyi defines the information environment as "the anthropogenic part of the space where subjects and objects of information processes, supported by the information infrastructure and related to the search, processing and storage of information and knowledge interact and self-organise" (Kalyuzhnyi, 2015). He also highlights such features of the information environment as openness, polymorphism, excessiveness, anthropogenicity and irreversibility.
A.D. Elyakov notes that in a narrow sense, the concept of "information environment" reflects the information processes existing in a society (Elyakov, 2012). The modern information environment is mainly determined by circulating and stored messages, information, knowledge and, above all, the latest scientific technologies (super-personal computers, telecommunication systems, satellite and cellular communications, databases, the Internet, etc.), as well as skilled people (electronic engineers, programmers, Internet users, etc.).

\section{Mechanisms for the social ties formation in the information environment}

It can be noted that studies of social networks created both in real and in virtual space are relevant both in Russian and foreign practice (Valitov, 2000; Whillans, 2016; Wu, Li, Evans, 2018).

Researchers note the development of artificial communications, transport and contacts, as well as methods for recording, storing and processing data (Izmailov, Poizner, 2012). D.B. Damskii and N.I. Koloskova (2018) note the impact of technology on social ties. They claim that technology eliminates the simplest ties between people, but greatly increases the quantitative indicator of social interaction and social relationships. Modern means of communication connect people at a great distance and give an opportunity to build relationships in constant communication with a partner. A. Groh (2016) considers the impact of mobile communications on indigenous peoples' ties. He notes an increase in the number of communications with relatives. At the same time, he notes the use of the native language to maintain such communications.

Classical interactionism, role theories and reference group theories state that an individual's behaviour is determined by three main factors - personality structure, role and reference group.

In case of social ties construction by representatives of dispersed living groups, such studies mainly relate to the consideration and identification of mechanisms for forming ties among migrants. N.L. Antonova (2016) considers foreign students studying at Ural Federal 
University. The author distinguishes the following main groups of ties which form the basis for social networks of migrants: educational activities (which connect foreign students, Russian students, faculty and organisational structures of the university which activities are associated with the educational process of migrants); daily activities (communication with fellow countrymen living in a hostel and supporting ethnic practices, as well as with external actors: bus conductors, shop assistants, medical staff, etc.); family ties (communication with those who stayed at home through email and social networks). S. Koelet, C. Van Mol and H.A. De Valk (2017) study social networks of European migrants with partners in Belgium and the Netherlands. They noted that over a period of time, the composition of social ties among such migrants changes. The number of contacts in the place of stay increases, and what is typical, the contacts are established either with fellow countrymen or with migrants in a similar situation. At the same time, ties with friends at home are weakened.

I.W.A. Wirawan (2018) considers the basics of building informal cultural ties between the Balinese ethnic community and the Sasak ethnic community in Mataram, West Nusa Tenggara province. As a result of the study, it was found that there are four factors of influence: cultural contact between the Balinese ethnic and Sasak ethnic communities during the historical period, the introduction of the Balinese culture and Sasak culture in Lombok, as well as cultural adaptation of each cultural identity and the construction of informal cultural ties as means of interethnic communication. Informal cultural ties are essential for maintaining integration between the Balinese and Sasak ethnic communities in Mataram.

\section{Conclusion}

Modern studies pay specific attention to the creation and maintenance of social ties in information environments. Researchers are particularly interested in migrant communities.

The study of modern social groups gives an opportunity to identify the features of social ties formation in difficult for adaptation environments. This allows to gain new knowledge about the adaptive mechanisms of people living remotely from each other and, nevertheless, having strong modern communities that successfully operate in the modern world and reproduce cultural memory of their own social identity.

Such features of social ties formation as the fact that the strongest ties are formed with relatives living remotely, as well as with fellow countrymen living in the same environment, are typical for dispersed ethnic groups. In addition, it is possible to note the expansion of these ties through mobile phones and Internet communications.

\section{References}

Adda, G., Stüker, S., Adda-Decker, M., Ambouroue, O., Besacier, L., Blachon, D., Kouarata, G.N. (2016). Breaking the Unwritten Language Barrier: The BULB Project. In Procedia Computer Science, 81, $8-14$.

Amosova, A.A., Koptseva, N.P., Sitnikova, A.A., Seredkina, N.N., Zamaraeva, Yu.S., Kistova, A.V., Reznikova, K.V., Kolesnik, M.A., Pimenova, N.N. (2019). Ethnocultural Identity in The Works of Krasnoyarsk Artists. In Journal of Siberian Federal University. Humanities \& Social Sciences, 12(8), 1524-1551. DOI: 10.17516/1997-1370-0463.

Antonova, N.L. (2016). Inostrannye studenty: sotsial'nye sviazi i seti. [International Students: Social Ties and Networks], 67.

Berestova, T.F. (2016). Bibliograficheskii iazyk: genezis, svoistva, funktsii i rol' v formirovanii i razvitii informatsionnogo prostranstva i sotsiuma [Bibliographic Language: Genesis, Properties, Functions and Role in The Formation and Development of The Information Space and Society]. In Vestnik kul'tury $i$ iskusstv [Bulletin of Culture and Arts], 2 (46).

Blaser, M., Feit, H.A., \& McRae, G. (Eds.) (2004). In The Way of development: Indigenous Peoples, Life Projects, and Globalization. Idrc. 
Callon, M. (1999). Actor-Network Theory - The Market Test. In The Sociological Review, 47(1_suppl), 181-195.

Coates, K., Coates, K.S. (2004). A Global History of Indigenous Peoples. Palgrave Macmillan UK.

Damskii, D.B., Koloskova, N.I. (2018). Vliianie IT-tekhnologii na sotsial'nye sviazi i obshchestvo [Influence of IT-Technologies on Social Relations and Society]. In Nauchnye issledovaniia i sovremennoe obrazovanie [Research and Modern Education], 155-158.

Dei, G.J., Hall, B.L., Rosenberg, D.G. (2000). Indigenous Knowledges in Global Contexts: Multiple Readings of Our World. Toronto, University of Toronto Press.

Drobizheva, L.M. (2013). Etnichnost' v sotsial'no-politicheskom prostranstve Rossiiskoi Federatsii. Opyt 20 let [Ethnicity in The Socio-Political Space of The Russian Federation. 20 Years Experience]. In Novyi khronograf [The New Chronograph].

Efimov, V.S., Lapteva, A.V., Mikhailova, E.I. (2016). Vliianie urbanizatsii na protsessy sokhraneniya kul'tury i iazyka naroda sakha: sotsiologicheskii analiz [The Impact of Urbanization on The Processes of Preserving the Culture and Language of The Sakha People: A Sociological Analysis]. In Arkheologiia, etnografiia i antropologiia Evrazii [Archeology, Ethnography, and Anthropology of Eurasia], 43(4), 127-134.

Elyakov, A.D. (2012). Homo informaticus i sovremennaia informatsionnaia sreda [Homo Informatics and Modern Information Environment]. In Filosofiia i obshchestvo [Philosophy and Society], (3), 38-59.

Bart, F. (2006). Etnicheskie gruppy i sotsial'nye granitsy. Sotsial'naia organizatsiia kul'turnykh razlichii [Ethnic Groups and Social Boundaries. Social Organization of Cultural Differences]. M., Novoe izdatel'stvo, 2006.

Golovnev, A.V. (2016). Kochevniki Arktiki: strategii mobil'nosti [Arctic Nomads: Mobility Strategies]. In Arkheologiia, etnografiia i antropologiia Evrazii [Archeology, Ethnography, and Anthropology of Eurasia], 44(4), 131-140.

Granovetter, M. (2009). Sila slabykh svyazei [The Strength of Weak Ties]. In Journal of Economic Sociology, 10(4), 31-50.

Groh, A. (2016). The Impact of Mobile Phones on Indigenous Social Structures: A Cross-Cultural Comparative Study.

Izmailov, I.V., Poizner, B.N. (2012). Slozhnost' sotsial'nykh sviazei i singuliarnost' d'iakova-vindzha [Complexity of Social Interactions and Dyakonov-Vinge Singularity]. In Vestnik Tomskogo gosudarstvennogo universiteta. Filosofiya. Sotsiologiya. Politologiшa [Bulletin of Tomsk State University. Philosophy. Sociology. Political Science], 4 (20), 1, 27-32.

Kalyuzhnyi, K.A. (2015). Informatsionnaia sreda i informatsionnaia sreda nauki: sushchnost' i naznachenie [The Information Environment and The Information Environment of Science: Essence and Purpose]. In Upravlenie naukoi i naukometriya [Management of Science and Scientometrics], (18).

Kastel's, M. (2000). Informatsionnaia epokha obshchestva i kul'tura [The Information Age of Society and Culture], p. 315.

Kistova, A.V., Pimenova, N.N., Reznikova, K.V., Sitnikova, A.A., Kolesnik, M.A., Khudonogova, A.E. (2019). Religion of Dolgans, Nganasans, Nenets and Enets. In Journal of Siberian Federal University. Humanities \& Social Sciences 12(5), 791-811. DOI: 10.17516/1997-1370-0424.

Koelet, S., Van Mol, C., De Valk, H.A. (2017). Social Embeddedness in a Harmonized Europe: The Social Networks of European Migrants with A Native Partner in Belgium and the Netherlands. In Global Networks, 17(3), 441-459.

Kolesnik, M.A., Libakova, N.N., Sertakova, E.A. (2018). Enets Language in the Studies of Domestic and Foreign Scientists. In Journal of Siberian Federal University. Humanities \& Social Sciences, 4 (11), 546-560.

Koptseva, N.P. (2014). Ekspertnyi analiz osnovnykh tendentsii ekonomicheskogo razvitiia korennyh malochislennyh narodov Severnoi Sibiri [Expert Analysis of The Main Trends in The Economic Development of The Indigenous Peoples of Northern Siberia]. In Economic Annals-XXI. 11-12, 93-96.

Koptseva, N.P. (2017). Expert Environmental Assessment, Specific for Indigenous Peoples of Siberian Arctic (on the Basis of Krasnoyarsk Region). Ekologiia Cheloveka [Human Ecology], 6, 30-35. 
Koptseva, N.P., Reznikova, K.V. (2015). Refinement of The Causes of Ethnic Migration of North Selkups Based on The Historical Memory of Indigenous Ethnic Groups of the Turukhansk District of Krasnoyarsk Krai. In Bylye Gody, 38 (4), 1028-1038.

Krevskii, I.G., Glotova, T.V., Dragunov, D.G., Matyukin, S.V. (2014). Informatsionnaia sreda setevogo vzaimodeistviia vuzov i real'nogo sektora ekonomiki [Information Environment of Network Interaction Between Universities and The Real Sector of The Economy]. In Sovremennye problemy nauki i obrazovaniya [Modern Problems of Science and Education], (6), 3-3.

Latour, B. (2011). Network Theory. Networks, Societies, Spheres: Reflections of an Actor-Network Theorist. In International Journal of Communication, 5, 15.

Maksimov, N.V. (2009). Informatsionnaia sreda nauki i obrazovaniia: ot informatsionnogo obsluzhivaniia k raspredelennoi sisteme upravleniya znaniiami [Information Environment of Science and Education: From Information Services to A Distributed Knowledge Management System]. In Informatsionnoe obshchestvo [Information Society], (6), 58-67.

Nazarov, M.M., Kovalev, P.A. (2014). Rossiiskaia informatsionnaua sreda: ispol'zovanie televideniia i interneta $\mathrm{v}$ kontekste mezhstranovykh sravnenii [Russian Information Environment: The Use of Television and The Internet in The Context of Cross-Country Comparisons]. In Informatsionnoe obshchestvo [Information Society], 1, 38-48.

Pronina, L.A. (2008). Informatsionnye tekhnologii v sokhranenii kul'turnogo naslediia [Information Technology in The Preservation of Cultural Heritage]. In Analitika kul'turologii [Analytics of Cultural Studies], (12).

Semenyuk, E.L. (2014). Informatsionnaia kul'tura obshchestva i progress informatiki [The Information Culture of Society and The Progress of Computer Science]. In NTI, 1(7), 3.

Seredkiva, N.N., Strucheva, E. (2018). Revival of the Evenki Language: Traditional and Modern Formats. In Journal of Siberian Federal University. Humanities \& Social Sciences, 4 (11), 615-628.

Shreider, Yu.A. (2008). Informatsionnye protsessy i informatsionnaia sreda [Information Processes and The Information Environment]. In Nauchno-tekhnicheskaia informatsiia. Seriia 2: Informatsionnye protsessy i sistemy [Scientific and Technical Information. Series 2: Information Processes and Systems], (9), 3-7.

Sitnikova, A.A. (2018). The World Practice of Development of Writing for Non-Literate Cultures. In Journal of Siberian Federal University. Humanities \& Social Sciences, 11(10), 1635-1652. DOI: 10.17516/1997-1370-0325.

Smirnov, M.A. (2001). Informatsionnaia sreda i razvitie obshchestva [Information Environment and The Development of Society]. In Informatsionnoe obshchestvo [Information Society], (5), 50-54.

Sokolov, M.S. (2013). V.I. Vernadskii i ego biosferologiia [V.I. Vernadsky and His Biospherology]. In Biosfera [Biosphere], 5(1).

Tishkov, V.A. (1994). Nationalities and Conflicting Ethnicity in Post-Communist Russia. In United Nations Research Institute for Social Development, 50.

Valitov, V.N. (2000). Sotsial'nye seti rossiiskikh immigrantov i korennykh zhitelei [Social Networks of Russian Immigrants and Indigenous People]. In Sotsiologicheskii zhurnal [Sociological Journal], (1-2), $112-120$.

Vernadsky, V.I. (1989). Mysli o noosfere. Biosfera i noosfera [Thoughts on the Noosphere. Biosphere and Noosphere]. M., Nauka, 178-242.

Whillans, A.V., Christie, C.D., Cheung, S., Jordan, A.H., Chen, F.S. (2017). From Misperception to Social Connection: Correlates and Consequences of Overestimating Others' Social Connectedness. In Personality and Social Psychology Bulletin, 43(12), 1696-1711.

White, H.C. (2008). Identity and Control: How Social Formations Emerge. Princeton University Press. Wirawan, I.W.A. (2018). Maintaining Social Relationship of Balinese and Sasak Ethnic Community. In International Journal of Social Sciences and Humanities, 2(1), 92-104.

Wu, L., Li, L., Evans, J. (2018). Social Connection Induces Cultural Contraction: Evidence from Hyperbolic Embeddings of Social and Semantic Networks. arXiv preprint arXiv:1807.10216. 
Zamaraeva, J.S., Sergeeva, N.A., Fil'ko, A.I. (2018). Measures on the Preservation of the Language of the Small-Numbered Indigenous Peoples Based on the Results of Field Studies and Scientific Research in the Evenk Municipal District of the Krasnoyarsk Krai. In Journal of Siberian Federal University. Humanities \& Social Sciences, 4(11), 679-694.

Zamaraeva, Y.S., Luzan, V.S., Metlyaeva, S.V., Seredkina, N.N., Koptseva, N.P., Fil'ko, A.I., Khrebtov, M.Y. (2019). Religion of The Evenki: History and Modern Times. In Journal of Siberian Federal University. Humanities \& Social Sciences, 12(5).

Zamaraeva, Yu.S. (2015). Global'nye transformatsii, kotorye perezhivaiut indigennye narody Severa [Global Transformations Experienced by Indigenous Peoples of The North]. In Sovremennye problemy nauki i obrazovaniia [Modern Problems of Science and Education], (1-1), 1882-1882.

\title{
Механизмы формирования социальных связей в информационной среде в современных отечественных и зарубежных исследованиях
}

\author{
С.В. Березюк, Н.П. Копцева, А.И. Филько \\ Сибирский федеральный университет \\ Российская Федерация, Красноярск
}

\begin{abstract}
Аннотация. В данной статье рассматривается отражение особенностей возникновения и закрепления социальных связей в работах российских ученых и зарубежных коллег. Основной акцент делается на исследованиях протекания данных процессов в современной информационной среде. Для полного понимания вопроса в статье разбираются понятия «социальные связи» и «информационная среда», а также их отражение в монографиях и научных статьях. Обобщаются отечественные и зарубежные исследования в данной области касательно мигрантов и представителей коренных малочисленных народов. Отмечаются особенности формирования социальных связей с родственниками, проживающими отдаленно, и земляками, проживающими в той же среде. Выделяются особенности расширения социальных связей посредством мобильных телефонов и коммуникаций в интернете.
\end{abstract}

Ключевые слова: социальные связи, информационная среда, формирование социальных связей, социальные связи мигрантов, социальные связи в информационной среде.

Исследование выполнено при финансовой поддержке РФФИ в рамках научного проекта № 19-39-90015. Исследование выполнено при финансовой поддержке РФФИ в рамках научного проекта № 19-311-90016.

Научная специальность: 22.00.00 - социологические науки. 